\title{
Bank Credit Development: A Study of Macro-prudential Effect
}

\author{
Sebastiana Viphindrartin ${ }^{1}$, Silvi Asna Prestianawati ${ }^{2}$, Ayman Nazzal $^{3}$ \\ ${ }^{1}$ Faculty of Economics and Business, University of Jember, Indonesia \\ ${ }^{2}$ Faculty of Economics and Business, Universitas Brawijaya, Indonesia \\ ${ }^{3}$ Faculty of Economics and Business, Palestine Technical University, Palestine \\ E-mail: silvi.febub@gmail.com
}

Received: July, 2019; Accepted: November, 2019; Published: December, 2019

Permalink/DOI: http://dx.doi.org/10.17977/um002v11i22019p177

\begin{abstract}
Macroprudential policy is a policy that leads to the analysis of the financials systems as whole as of financials individuals including banking. This research want to show the effect of macroprudential policy on the development of banking credit in Indonesia by using monthly time series data from January 2010 until June 2017. This research uses several variables namely credits, exchange rates, Return on Assets (ROA), Loan to Deposits Ratio (LDR), Capitals Adequacy Ratio (CAR) and interest rates. The method used in this research is using Autoregressive (VAR). The result of this study indicate that macroprudential policy has an effect on the development of bank credit in Indonesia. Macroprudential policy that is Loan to Deposits Ratio (LDR) has an influence in improving credit development in Indonesia. In addition, the change in interest rate from the BI Rate to BI 7 Day Repo Rate affect the development of credit in Indonesia. Profit earned and capital owned by banks also affects the development of credit in Indonesia. These results are supported by Impulse Response Function (IRF) and Variance Decompotition (VD) tests where macroprudential policy appears stable in response to credit shocks.
\end{abstract}

Keywords: Macroprudential Policy, Credit, VAR

JEL Classification: E51

\section{INTRODUCTION}

A strong introduction engages the reader in the problem of interest and Macroprudential policy is a policy that leads to the analysis of the financial system as a whole as a collection of financial individuals including banking. Macroprudential policies can prevent and mitigate systemic risk, encourage more balanced and quality intermediation function, and improve financial system efficiency and financial access. The financial system is a framework or system that facilitates savings and loan of funds or money (the function of banking intermediation). The stability of the financial system depends on the health of financial institutions and financial market stability. The financial system has an important role in the economy where the financial system can help reallocate resources especially the funds so that excessive funds from the excess funds can be utilized by the under-funded parties.

Banking is one of the economic sectors within the framework of a very important financial system role in the economic development of Indonesia. Because economic growth will be faster with better banking role. The role of good banking 
can be seen from the efficiency of each banking. Efficiency is a performance parameter that theoretically underlies the entire performance of a company. Ability to produce maximum output with existing input. Banking efficiency is one of the indicators that can know and analyze the strength of a bank. With the identified input output allocation, it can be further analyzed to see the cause of inefficiency (Jiang et al., 2019).

Systemic risk becomes an empirical debate in various studies conducted in developed and developing countries. Schularsik and Taylor (2012) show that the importance of credit as a guide in understanding the financial cycle as well as its impact on the crisis. Research from Calderon and Kubota (2012) suggests that private capital inflows may encourage a credit boom. In mitigating systemic risks not only can be done using one indicator, but a comprehensive set of measuring tools (Aaron,2015) is required. Risks can be addressed using macroprudential policy instruments, a study conducted by Lim et al. (2011) argue that the increasing number of instruments used will be more effective in reducing the procyclicality and effectiveness of the shocks caused by the financial sector. The familiarity of macroprudential policy in Spain can help in overcoming the increasing credit losses during the global financial crisis.A research conducted by Purnawan and Nasir (2015) in analyzing macroprudential policy roles in

Indonesia found that the movement of macroprudential policy components done after the 2008 financial crisis is relatively following the average of economic conditions, especially in terms of encouraging optimal GWM + LDR policies in risk management credit and maintain the volatility of the rupiah. Credit growth and changes in the ratio of credit to GDP have the best and most significant signal properties against credit to GDP in almost all policies (Gersl and Jasova, 2018). A study conducted by Surjaningsih et al. (2014) indicates that the bank's liquidity ratio could signal a year before the 2008 financial crisis.

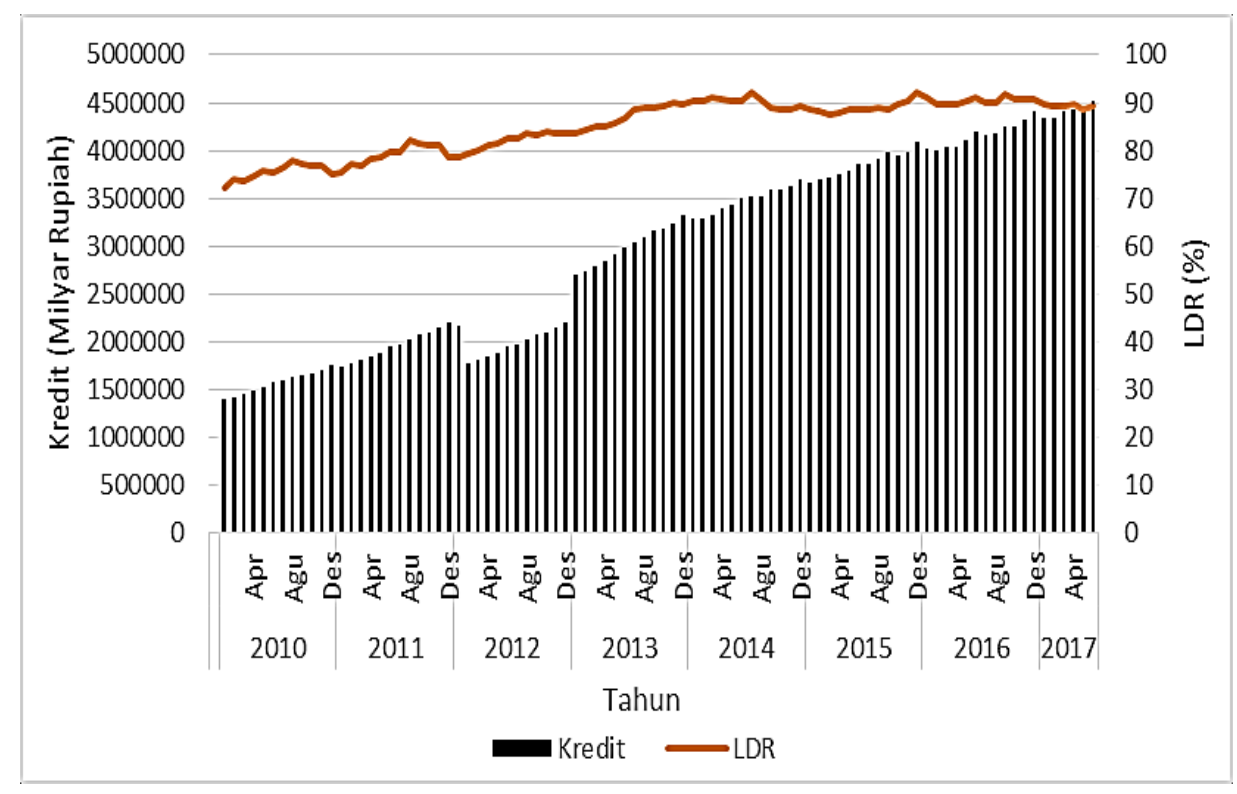

Figure 1. Development of Credit and LDR (Source: Financial Services Authority (OJK) 
Broadly speaking, the development of bank credit in Indonesia has increased. In 2010 to 2011 banking credit movement increased, then at the end of 2011 credit movement showed a decline. In 2012 the movement of credit is lower than the previous year. From the year 2013 to June 2017 the movement of credit shows its essence with the continuous increase of credit by banks. The movement of Loan to Deposite Ratio (LDR) continued to increase from during the observation period although the increase was not significant. In the period 2013 2017 which ranges in the number $83.47 \%$ - 89.31\%. In 2012, the increasing movement of LDR is not accompanied by credit growth, the high ratio of loans provided by banks is not responded by credit growth. This is evidenced by the decline in loan growth in 2012 than in the previous year although the LDR has increased. Increased credit movement is also not accompanied by good banking performance, global economic pressures and declining oil prices since mid-2014 have an impact on the mining sector. These conditions resulted in slightly declining credit growth (Bank Indonesia, 2016). The implementation of macroprudential policy in managing credit development became the background in this research. The focus in this research is to know how the role of macroprudential policy in managing credit growth of banking sector.

\section{METHOD}

This research uses Vector Autoregressive (VAR) method. Vector Autoregressive was introduced by C. A Sims (1972) as thought of Granger (1969) which was then used extensively in econometrics. Granger says if two variables, eg $\mathrm{x}$ and $\mathrm{y}$ have a causal relationship where $\mathrm{x}$ affects $\mathrm{y}$ then $\mathrm{x}$ 's past information can help predict $\mathrm{y}$. There are several advantages VAR, one of which is a simple model, so no need to determine the endogenous and exogenous variables because all variables are endogenous. The general VAR equation according to Baum (2013) is as follows:

$$
y_{t}=v+A_{1} y_{t-1}+\cdots+A_{p} y_{t-p}+B_{0} x_{t}+B_{1} X_{t-1}+\cdots+B_{s} X_{t-s}+u_{t}
$$

where is the vector of the variable $\mathrm{K}$, each model as a function of lag $\mathrm{p}$ for each variable and always put the exogenous variable. Assumed that :

$$
\left(u_{t}\right)=0, E\left(u_{t} u_{t}^{s}\right)=\Sigma \text { and } E\left(u_{t} u_{g}^{s}\right)=0 \forall t \neq s
$$

The method used to know how much influence of exchange rate, Return on Assets (ROA), Loan to Deposits Ratio (LDR), Capital Adequacy Ratio (CAR) and interest rate to credit. The equation model in this research is as follows:

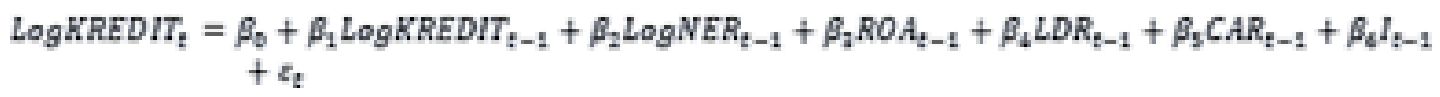

\section{RESULTS AND DISCUSSION}

A stable financial system will be able to allocate resources and absorb shocks that may prevent disruptions to real sector activities and financial systems. The rapid development of credit shows that the role of banks is very important 
in financing infrastructure in Indonesia so that the availability of credit in the economy is highly dependent on banking behavior. The instability in the financial sector can be affected by internal or external shocks. Such instability can lead to credit, liquidity, market and operational risks so that macro prudential policies are used to limit the risks and costs that may arise from the instability of the financial system.

\section{Response of DLOGKRD to DLOGNER}

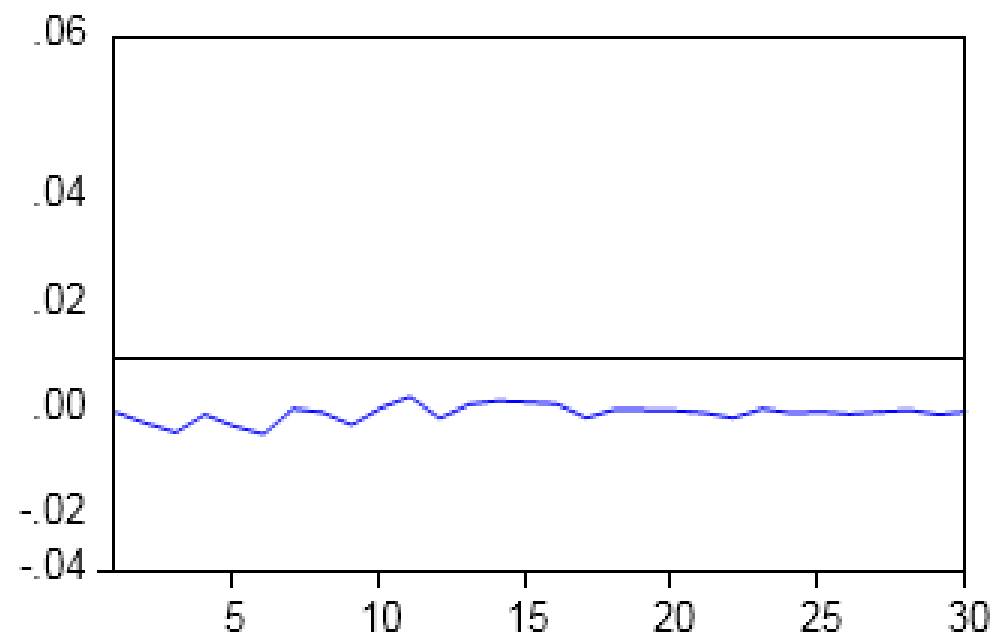

Figure 1. Impulse Response Function Result of Credit to Exchange Rate

The effect of shocks from credit variables, exchange rates, ROA, LDR, CAR and interest rates can be seen through impulse response function (IRF) in VAR model analysis (see figure 1). The results of the IRF test show that credit response to exchange rate shocks is stable and vice versa, the exchange rate response to credit shocks is stable in Indonesia. The statement indicates that both credit and exchange rate have a great influence in Indonesia. This study is in line with book of Green (2018) which states that changes in exchange rates will affect the decision on credit. The result is supported by the banking capital that is still secure so that credit growth in Indonesia continues to grow. The Indonesian banking industry has also developed a number of strategies to deal with the weakening of the rupiah exchange rate, in the case of credit channeling of its banks, mostly to the micro, small and medium enterprises. 


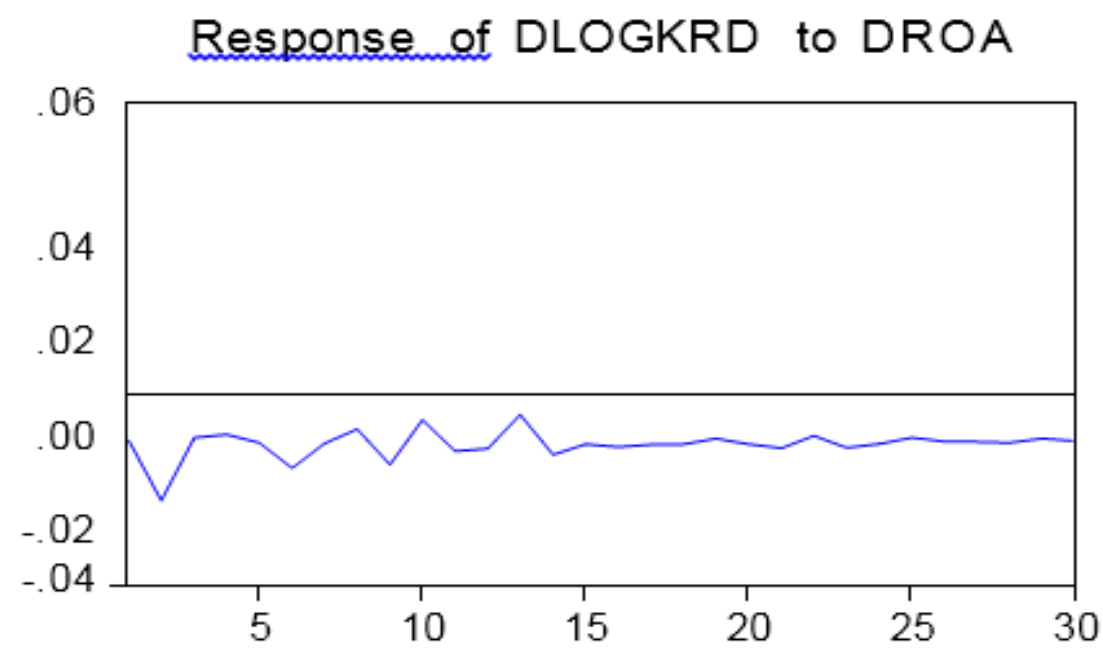

Figure 2. Impulse Response Function Result of Credit to ROA

Figure 2 indicates that credit on ROA shocks appears stable and vice versa, the ROA response to credit shocks is stable, meaning that both credit and ROA are equally influential. This study is in line with the theory where ROA is an indicator that indicates that if ROA increases then bank asset has been used optimally to gain profit so that ROA and credit have a positive relationship (Kusumasturi,2019). The greater the ROA of a bank, the greater the rate of profit achieved so that the bank has the opportunity to channel its credit is greater. This study concurs with the research of Effendi (2018) which states that ROA has a positive and significant impact on credit development.

Response of DLOGKRD to DLDR

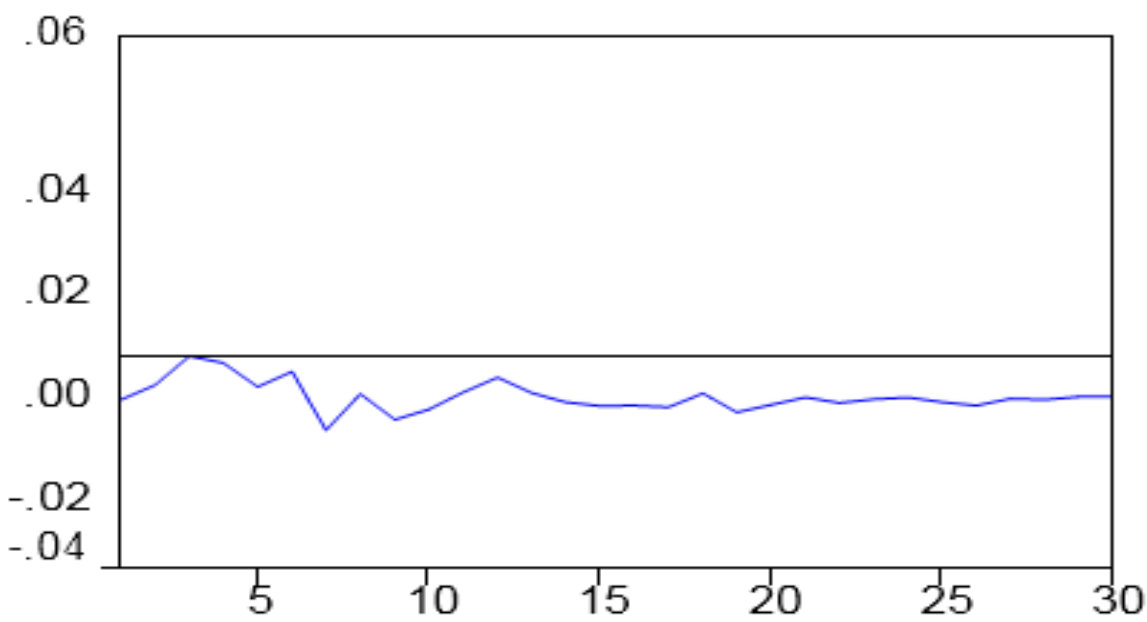

Figure 3. Impulse Response Function Result of Credit to LDR

From figure 3 we see that LDR responds to stable credit shocks as well as on the contrary, credit response to LDR is stable in Indonesia, indicating that both LDR and credit have a big influence. This research is in line with the policy of Bank Indonesia in Bank Indonesia Regulation Number 17/11 / PBI / 2015 which is to encourage economic growth through banking credit growth, adjustment of GWM 
policy through LDR calculation. This study concurs with the research of Yuliana (2014) which shows that LDR has a significant effect on lending. Macro prudential policy by using LDR instrument is very influential to the development of credit in Indonesia where the higher LDR in a bank hence credit ability which has been channeled by banking also higher, this is indicated by the development of LDR period 2013 - 2017 which is around $83.47 \% 89.31 \%$ as well as the continuous development of credit during the observation period.

Response of DLOGKRD to DCAR

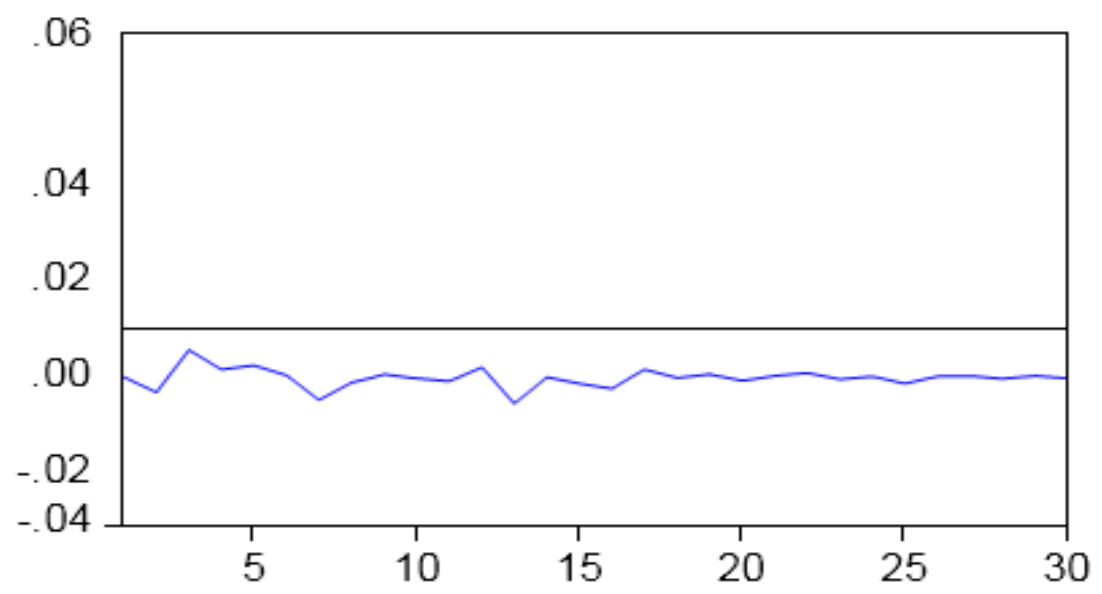

Figure 4. Impulse Response Function Result of Credit to CAR

Credit response to CAR shocks is stable and vice versa, the CAR response to credit is stable, indicating that both credit and CAR have a big influence (see figure 4). Rachman et al (2018) argues that there are two internal factors that affect the volume of credit granting CAR and ATMR. Factors that usually influence banking behavior in offering credit are caused by low banking assets, high Non Performing Loan (NPL) or a drop in banking capital due to depreciation, thus decreasing the ability of banks to provide loans (Kingu, 2018). This study concurs with the research of Yuliana (2014) who argues that CAR has a significant influence on credit.

This research is supported by Bank Indonesia Regulation Number 3/21 / PBI / 2001 concerning the obligation of minimum capital provision for commercial banks, in which each bank is required to provide minimum capital of $8 \%$ of riskweighted assets procured by CAR. This regulation is supported also by the development of CAR during the observation period which ranges from $18.66 \%$ $-22.75 \%$. This research is in line with the above- mentioned theory which states that the behavior of banks in offering credit is very influential on the CAR so it can be said that the greater the value of CAR then the possibility of banks to make credit offer is also greater. 


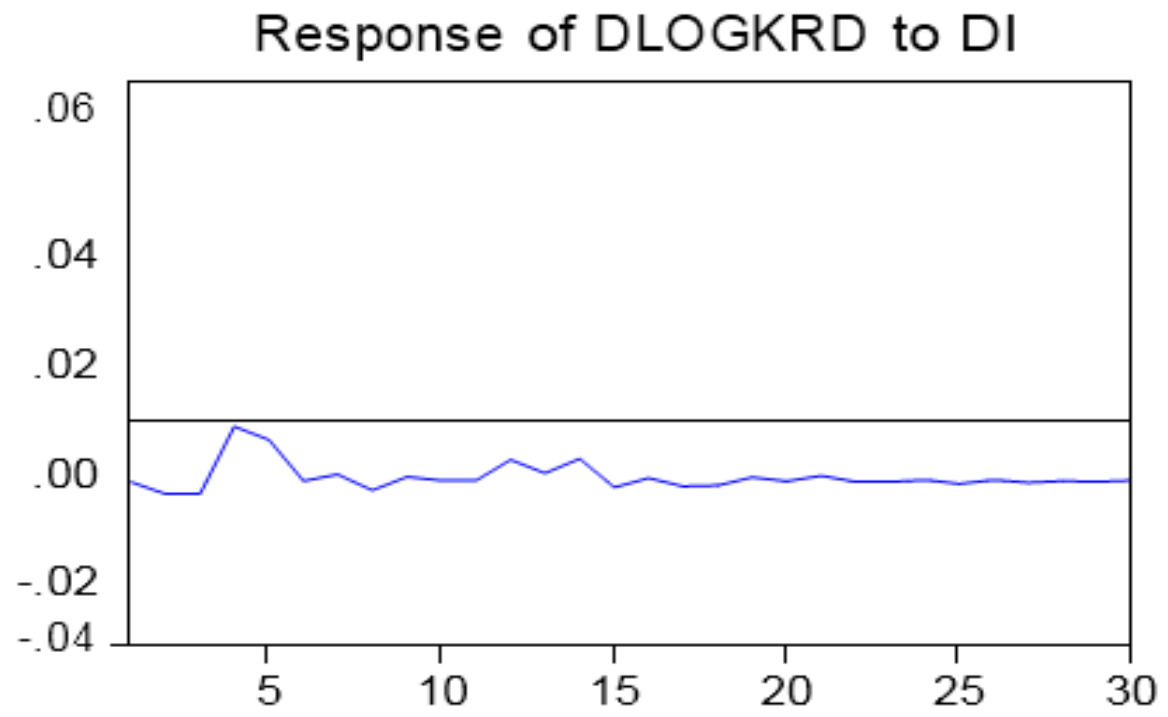

Figure 5. Impulse Response Function Result of Credit to Interest Rate

Credit responds to interest rate shocks is stable and vice versa, the interest rate response to credit shocks is stable. The statement indicates that both credit and interest rates have a large influence. This research is supported by research conducted by Dawood (2018) who argue that interest rates have an effect on the amount of credit in Indonesia. In 2017, Bank Indonesia's interest rate decline to be $4.50 \%$, this is done to improve banking liquidity. The decline in interest rates was responded by banks, so that demand for loans is higher than the previous year due to lower loan interest rates.

\section{CONCLUSION}

Based on the results of the analysis using Vector Autoregressive (VAR) method on the effect of exchange rate, ROA, LDR, CAR and interest rate on credit, it can be concluded as follows: a) Exchange rates have a significant effect both positive and negative on credit, this indicates that if there is a change in the exchange rate it will affect the development of credit in Indonesia; b) ROA has a significant influence both positive and negative to credit, it indicates that if there is a change to the ROA it will affect the development of credit in Indonesia; c)LDR has a significant influence both positive and negative on credit, it indicates that if there is a change to LDR it will affect the development of credit in Indonesia; d) CAR has a significant effect both positive and negative on credit, it indicates that if there is a change to the CAR it will affect the development of credit in Indonesia; and e) Interest rates have a significant effect both positive and negative on credit, this indicates that if there is a change in interest rates it will affect the development of credit in Indonesia. 


\section{REFERENCES}

Baum, Christopher F. (2013). VAR, SVAR and VECM models. Boston College. Retrieved from http://fmwww.bc.edu/ECC/S2013/823/EC823.S2013.nn10.slides.pdf

Bank Indonesia. (2016). Mengupas Kebijakan Makroprudensial. Jakarta: Bank Indonesia.

Calderon, C. and M. Kubota. (2012). Gross Inflows Gone Wild: Gross Capital Inflows, Credit Booms and Crises. World Bank Group, Economic Research. Retrieved from https://editorialexpress.com/cgibin/conference/download.cgi?db_name=FEMES12\&paper_id=148

Dawood, Taufiq Carnegie. (2018). Monetary Policy, Foreign Interest Rate impact on Indonesian Bank Credit. Journal of Economics and Policy. 11(2).pp 338355. https://doi.org/10.15294/jejak.v11i2.16056

Effendi,Maya, R.Budi, M,Mumun (2018). The Determinants of Banking Credit Disburshment and its Implications on the Return on Assets (ROA): Empirical Study to the Banks Listed on Indonesian Stock Exchange. International Journal of Applied Business and Economic Research. 15(22)

Gersl, Adam \& Martina Jasova. (2018). Credit-based Early Warning Indicators of Banking Crises in Emerging Markets. Economic System. 42 (1), 18-3. https://doi.org/10.1016/j.ecosys.2017.05.004

Green. Gary P. (2018). Finance Capital And Uneven Development.Westview Press. New York

Jiang,Yongzhong.,Xueli C.,Vivian V.,\& Tomas,B. (2019). Evaluating Economic and Environmental Performance of the Chinese Industry Sector. Sustanaibility, 11 (6084). doi:10.3390/su11236804www

Kingu, Peter, S.Macha, R. Gwahula. (2018). Impact of Non-Performing Loans on Bank's Profitability: Empirical Evidence from Commercial Banks in Tanzania . International Journal of Scientific Research and Management. doi: 10.18535/ijsrm/v6i1.em11

Kusumastuti, W.Intan \& A. Alam (2019). Analysis of impact of CAR,BOPO,NPF on profitability of Islamic Banks (Year 2015-2017). Journal of Islamic Economic Laws. 2(1).pp 30-59

Lim, C.et al (2011).Macroprudential Policy: What Instruments and How to Use Them?. IMF Working Paper, No. WP/11/238

Mehrotta,Aaron \& Y.James. (2015). Financial inclusion - issues for central banks. BIS Quarterly Review. Retrieved from https://www.bis.org/publ/qtrpdf/r_qt1503h.pdf

Purnawan, Muhammad Edhie \& M. Abd. Nasir. (2015). The role of macroprudential policy to manage eExchange rate volatility, excess banking liquidity and credits. Buletin Ekonomi Moneter dan Perbankan, Vol. 18 No. 1

Rachman, R. Arrina, Y.B. Kadarusman, K. Anggriono \& R. Setiadi (2018). Bankspecific Factors Affecting Non-performing Loans in Developing Countries: Case Study of Indonesia. The Journal of Asian Finance, Economics and Business. 5(2).pp 35-2

Schularick, Moritz \& A.M. Taylor (2012). Credit Booms Gone Bust: Monetary Policy, Leverage Cycles, and Financial Crises, 1870-2008. American 
Economic Review, 102(2): 1029-1061 http://dx.doi.org/10.1257/aer.102.2.1029

Surjaningsih, Ndari, Y.Diana \& D.Elis.( 2014). Early warning indicator risiko likuiditas perbankan. Bank Indonesia. Working Paper, No. WP/1/2014

Yuliana, Amalia. (2014). Pengaruh LDR, CAR, ROA dan NPL Terhadap Penyaluran Kredit Pada Bank Umum di Indonesia Periode 2008 - 2013. Jurnal Dinamika Manajemen.2(3) 